Check for updates

Cite this: RSC Adv., 2019, 9, 34601

\title{
Low-temperature all-solid-state lithium-ion batteries based on a di-cross-linked starch solid electrolyte $\uparrow$
}

\begin{abstract}
Zehua Lin (iD) and Jin Liu (iD *
The preparation of a low-temperature solid electrolyte is a challenge for the commercialization of the allsolid-state lithium-ion battery (ASSLIB). Here we report a starch-based solid electrolyte that displays phenomenal electrochemical properties below room temperature (RT). The starch host of the electrolyte is synthesized by two cross-linking reactions, which provide sufficient and orderly binding sites for the lithium salt to dissolve. At $25{ }^{\circ} \mathrm{C}$, the solid electrolyte has exceptional ionic conductivity $(\sigma, 3.10 \times$ $\left.10^{-4} \mathrm{~S} \mathrm{~cm}^{-1}\right)$, lithium-ion transfer number $\left(t^{+}, 0.82\right)$ and decomposition potential $(\mathrm{dP}, 4.91 \mathrm{~V})$. At $-20^{\circ} \mathrm{C}$, it still has outstanding $\sigma\left(3.10 \times 10^{-5} \mathrm{~S} \mathrm{~cm}^{-1}\right), t^{+}(0.72)$ and $\mathrm{dP}(5.50 \mathrm{~V})$. The $\mathrm{LiFePO}_{4}$ ASSLIB assembled with the electrolyte exhibits unique specific capacity and long cycling life below RT, and the $\mathrm{LiNi}_{0.8} \mathrm{CO}_{0.1} \mathrm{Mn}_{0.1} \mathrm{O}_{2}$ ASSLIB can operate at $4.3 \mathrm{~V}$ and $0{ }^{\circ} \mathrm{C}$. This work provides a solution to solve the current challenges of ASSLIBs to widen their scope of applications.
\end{abstract}

Received 25th September 2019 Accepted 18th October 2019

DOI: $10.1039 / \mathrm{c} 9 \mathrm{ra07781b}$

rsc.li/rsc-advances
Starch is a kind of bio-molecules composed of a sixmembered ring of glucose monomer and alkyl chain in series, which has been demonstrated to be a multifunctional material for SPE. ${ }^{8}$ More importantly, it is equipped with two ether oxygen bonds and three hydroxyl $(-\mathrm{OH})$ groups per monomer for dissociation of lithium salt and conduction of lithium ions. Because the $\mathrm{p} K_{\mathrm{a}}$ of starch is 13 at $40{ }^{\circ} \mathrm{C},{ }^{9}$ the $-\mathrm{OH}$ groups will completely ionize into $\mathrm{H}^{+}$and $-\mathrm{O}^{-}$when $\mathrm{pH}>13$. The $-\mathrm{O}^{-}$will combine with $\mathrm{Li}^{+}$through an ionic bond that is too stable to release the lithium ion, leading to unconductible "dead" lithium ion. When $\mathrm{pH}<13$, the $-\mathrm{OH}$ groups will form hydrogenbonded nets that are strongly hydrophilic and may react with lithium metal anode, especially at $\mathrm{pH}>13$, resulting in a fast corrosion due to a black coat of the irreversible Li compound. ${ }^{\mathbf{1 0}}$

In order to prevent corrosion and "dead" $\mathrm{Li}^{+}$, the $-\mathrm{OH}$ can be modified to form a weaker bond to lithium ion. For example, - OH bonds in starch reacted with a crossing linker (KH560) to produce -O-Si-O- bonds. ${ }^{11}$ Such a structure is able to provide both more and shorter pathways for lithium ion transfer than PEO can. ${ }^{12}$ However, the drawback is the incomplete crosslinking from the residual of $-\mathrm{OH}$ groups, probably due to the influence of steric hindrance to the cross-linking reaction, which may be reflected in the inferior film-forming property. ${ }^{13}$

On another note, boron (B) is preferable receptors for anions. ${ }^{14}$ On account of this, a solid electrolyte host was synthesized by cross-linking poly(ethylene glycol) (PEG) with borane $\left(\mathrm{BH}_{3}\right) .{ }^{15}$ When the electrolyte was assembled into an allsolid-state $\mathrm{LiFePO}_{4}$ (LFP) battery, it can work from RT to $140{ }^{\circ} \mathrm{C}$.

In this work, we develop a low temperature solid electrolyte host through two cross-linking reactions, in which KH560 as a larger cross-linker reacts with starch first to form a starch-Si
School of Metallurgy and Environment, Central South University, Changsha, 410083, P. R. China. E-mail: jinliu@csu.edu.cn

$\dagger$ Electronic supplementary information (ESI) available: Detailed description of materials, preparation, experimental methods and additional data including figures and tables. See DOI: 10.1039/c9ra07781b 
(StSi) precursor, and $\mathrm{BH}_{3}$ as a smaller cross-linker continues to cross-link with the residual of $-\mathrm{OH}$ groups. With constructing an orderly ether-bonded net for lithium salt dissolution and hybridizing organic compounds with inorganic elements of $\mathrm{B}$ and $\mathrm{Si}$ at a molecular level, a solid electrolyte host of B-Starch-Si (BStSi) is synthesized, of which a schematic diagram for the reactions is shown as Fig. 1 a.

Based on above design, the BStSi SPE possesses excellent flexibility and high lithium ion transferring ability at low temperature. Moreover, an outstanding electrochemical performance is achieved below RT for ASSLIBs assembled by the BStSi SPE, LFP/NCM811 cathode and lithium metal anode. Photos of the freestanding and flexible BStSi SPE (flat and fold) are shown as Fig. S1. $\dagger$ Moreover, the safety performance of BStSi based ASSLIB is confirmed with puncturing experiment, shown as Fig. S2.†

\section{Experiment}

\section{Materials}

The reagent grade corn starch and $\gamma$-(2,3-epoxypropoxy)propyltrimethoxy-silane (KH560) were purchased from Aladdin. Borane-tetrahy-drofuran $\left(\mathrm{BH}_{3} / \mathrm{THF}, 1 \mathrm{~mol} \mathrm{~L}^{-1}\right.$ in THF) and lithium bis(tri-fluoromethylsulfonyl)imide (LiTFSI > 99\%) were obtained from J\&K company. All solvents and other reagents were of analytical grade and used without further purification.

\section{Synthesis and characterization of BStSi solid electrolyte host}

$30.000 \mathrm{~g}$ dimethyl sulfoxide (DMSO) was added in a flask to dissolve $1.000 \mathrm{~g}$ starch and stirred at $90^{\circ} \mathrm{C}$. $\mathrm{KH} 560$ was added in the flask at certain molar ratios of starch monomer : KH560 = $10: 9,7: 6,5: 4,3: 2$ and $2: 1$. This cross-linking reaction was carried out at $90{ }^{\circ} \mathrm{C}$ in argon atmosphere for $12 \mathrm{~h}$ to produce the St-Si precursor. After that, the temperature was decreased to $25{ }^{\circ} \mathrm{C}$ by a Cryogenic bath, and added $\mathrm{BH}_{3} / \mathrm{THF}$ in the precursor at the molar ratio of $\left(\mathrm{BH}_{3}+\mathrm{KH} 560\right):$ starch monomer $=1: 1$.
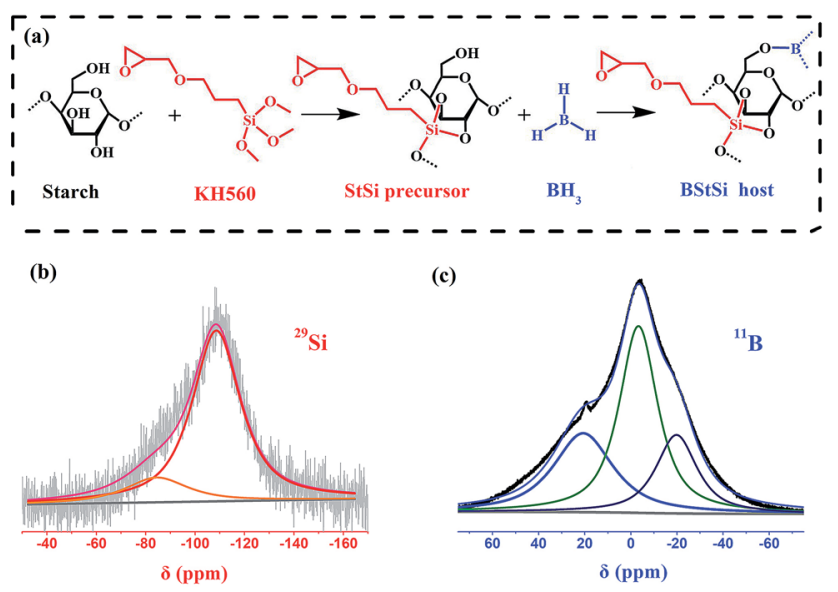

Fig. 1 (a) A possible chemical structure of the BStSi host. (b) ${ }^{29} \mathrm{Si}$ and (c) ${ }^{11} \mathrm{~B}$ liquid NMR of the BStSi host. Both of them are tested with a Teflon NMR tube.
This reaction lasted for $12 \mathrm{~h}$, and a transparent solution was obtained. The solution was dried at $60{ }^{\circ} \mathrm{C}$ for $16 \mathrm{~h}$ in a glove box to form the BStSi solid electrolyte host.

Liquid ${ }^{29} \mathrm{Si}$ and ${ }^{11} \mathrm{~B}$ NMR (BRUCKER, AVANCE III $400 \mathrm{MHz}$, Switzerland) of the BStSi solid electrolyte host that was redissolved in d-DMSO solvent were performed to examine the extent of the cross-linking reactions. Fourier transform infrared spectroscopy (FTIR) (BRUCKER, TENSOR II, Germany) was used in characterization of the chemical structure. Thermal stability was examined by thermogravimetry analysis (TGA, SDTQ-600, TA, USA) with about $10 \mathrm{mg}$ samples heated from room temperature to $800{ }^{\circ} \mathrm{C}$ under argon atmosphere at a heating rate of $10{ }^{\circ} \mathrm{C} \min ^{-1}$.

\section{Electrochemical properties tests of the BStSi solid electrolyte}

LiTFSI was added directly to the BStSi host. The solution was mixed and dried in an argon glove box at $60{ }^{\circ} \mathrm{C}$ for $16 \mathrm{~h}$ to form the BStSi solid electrolyte film (BStSi). The weight contents of LiTFSI varied from $20 \mathrm{wt} \%$ to $60 \mathrm{wt} \%$. The ionic conductivity $(\sigma)$ was determined by alternative current (AC) impedance spectroscopy. The BStSi film was sandwiched by two stainless steel plates $(d=16 \mathrm{~mm})$ to structure a SS/BStSi/SS cell. The sweep frequency ranged from $1 \mathrm{MHz}$ to $1 \mathrm{~Hz}$ with $\mathrm{AC}$ amplitude of $10 \mathrm{mV}$. The $\sigma$ was calculated by the following equation:

$$
\sigma=\frac{l}{S R_{\mathrm{b}}}
$$

where $l$ refers to the thickness of electrolyte, $S$ refers to the contact area between electrode and electrolyte and $R_{\mathrm{b}}$ refers to the bulk resistance of the electrolyte, which was obtained from the AC impedance spectrum intersection with the real axis. The tests were conducted with an electrochemical workstation (PARSTAT 4000, Princeton Applied Research, USA) and the temperature was controlled by a high-low temperature chamber (SDH4005P, HAOYUAN CO., China).

The $\mathrm{Li}^{+}$transference number $\left(t^{+}\right)$of the solid electrolyte was evaluated by a direct current (DC) polarization/AC impedance method using a $\mathrm{Li} / \mathrm{BStSi} / \mathrm{Li}$ cell and calculated by the following equation: ${ }^{16}$

$$
t^{+}=\frac{I_{\mathrm{ss}}\left(U-I_{0} R_{0}\right)}{I_{0}\left(U-I_{\mathrm{ss}} R_{\mathrm{ss}}\right)}
$$

where the $U$ refers to the DC voltage applied to the cell, $R_{0}$ and $R_{\mathrm{ss}}$ are the initial and steady-state polarization resistance respectively, $I_{0}$ and $I_{\mathrm{ss}}$ are the initial and steady-state polarization current respectively.

The decomposition potential of the solid electrolyte film was tested by cyclic voltammetry using a SS/BStSi/Li cell. The scan route is $3 \mathrm{~V} \rightarrow-1 \mathrm{~V} \rightarrow 6 \mathrm{~V}$ at a scan rate of $10 \mathrm{mV} \mathrm{s}^{-1}$.

The compatibility of the BStSi solid electrolyte with lithium was tested by a constant current polarization using a $\mathrm{Li} / \mathrm{BStSi} / \mathrm{Li}$ cell. The current was maintained $0.02 \mathrm{~mA}$ for 70 cycles, then increased to $0.05 \mathrm{~mA}$ and $0.1 \mathrm{~mA}$ each for 50 cycles, finally returned to $0.02 \mathrm{~mA}$ for 100 cycles, and each cycle was consisted of $0.5 \mathrm{~h}$ charge and $0.5 \mathrm{~h}$ discharge period with $5 \mathrm{~min}$ repose in between. 


\section{Performance tests of the BStSi all solid-state lithium ion batteries}

The $\mathrm{LiFePO}_{4}(\mathrm{LFP}) / \mathrm{BStSi} / \mathrm{Li}$ batteries (sealed in 2025 coin cell) were assembled with LFP as cathode $(d=10 \mathrm{~mm})$, BStSi as solid electrolyte and lithium metal wafer as anode $(d=16 \mathrm{~mm})$. The cathode was fabricated using LFP mixed directly with conductive carbon (Super P, SP) and polyacrylic acid (PAA) at a mass ratio of LFP:SP : PAA $=7: 2: 1$. Galvanostatic charge/ discharge cycling at $0{ }^{\circ} \mathrm{C}$ and $-20{ }^{\circ} \mathrm{C}$ was performed in a battery test system (LAND CT2001A, BTRBTS, China) and the batteries were held in a fridge (Haier, BCD-220WDVL, China). The cut-off voltages of the charge and discharge process were set at $2.5 \mathrm{~V}$ and $4.0 \mathrm{~V}$ respectively.

The lithium diffusion coefficient $(D)$ in the LFP electrode was calculated using the following equation. ${ }^{17}$

$$
D=\frac{R^{2} T^{2}}{2 A^{2} n^{4} F^{4} C^{2} \sigma^{2}}
$$

where, $R$ refers to the gas constant, $T$ refers to the absolute temperature, $A$ refers to the surface area of the cathode, $n$ is the number of electrons per molecule attending the electronic transfer reaction, $F$ is Faraday constant, $C$ is the concentration of lithium ions in the LFP electrode, which can be obtained from the density and the molecular weight of the materials. ${ }^{18}$ The $\sigma$ is the Warburg factor, which has the relationship with $Z_{\text {re }}$

$$
Z_{\mathrm{re}}=R_{\mathrm{b}}+R_{\mathrm{ct}}+\sigma \omega^{-1 / 2}
$$

where the $R_{\mathrm{b}}$ refers bulk resistance, $R_{\mathrm{ct}}$ refers to the charge transfer resistance and $\omega$ is the angular frequency, which has the relationship with the frequency $(f)$ as follow

$$
\omega=2 \pi f
$$

The graph of $Z_{\mathrm{re}}$ against $\omega^{-1 / 2}$ in the low frequency region is a straight line with the slope of $\sigma$, and the $Z_{\mathrm{re}}-\omega^{-1 / 2}$ plots were presented in Fig. $\mathrm{S} 10^{\dagger}$ and the values were depicted in Table S2.†

The $\mathrm{LiNi}_{0.8} \mathrm{Co}_{0.1} \mathrm{Mn}_{0.1}(\mathrm{NCM} 811) / \mathrm{BStSi} / \mathrm{Li}$ batteries were assembled with NCM811 cathode, BStSi solid electrolyte and lithium anode. The NCM811 cathode was prepared at a mass ratio of NCM811 : SP : PVDF $=8: 1: 1$. The cycle performance at $45{ }^{\circ} \mathrm{C}$ was tested with a battery warming in an oven with temperature accuracy of $\pm 1{ }^{\circ} \mathrm{C}$. The discharge cut-off voltage was set at $2.5 \mathrm{~V}$. The charge cut-off voltage was started at $4.0 \mathrm{~V}$ and was increased by $0.1 \mathrm{~V}$ for each 5 cycles.

\section{Discussion}

\section{Structure characterization}

In order to confirm the structure of BStSi, the liquid ${ }^{29} \mathrm{Si}$ and ${ }^{11} \mathrm{~B}$ NMR were conducted with a Teflon tube (silicon and boron free) to eliminate the background signal. As shown in Fig. 1b, the curve of ${ }^{29} \mathrm{Si} \mathrm{NMR}$ is constructed with two peaks. At $-109 \mathrm{ppm}$, it is a $\mathrm{Q}^{4}$ peak of silicon, which is ascribed to a threedimensional cross-linked framework ${ }^{\mathbf{1 9}}$ derived from the $-\mathrm{Si}-$
O- bonds of KH560 grafting with - $\mathrm{OH}$ groups of starch molecules. At $-83 \mathrm{ppm}$, it is the $\mathrm{Q}^{1}$ peak that is assigned to a siliconcontaining group seated at the end of a chain, ${ }^{20}$ which may belong to uncross-linked silicon in KH560.

In Fig. 1c, the ${ }^{11} \mathrm{~B}$ NMR curve can be divided into three peaks. The peak at $19.3 \mathrm{ppm}$ is ascribed to $\mathrm{B}(-\mathrm{O}-\mathrm{C}-)_{3}$-like structure, confirming that $\mathrm{BH}_{3}$ has cross-linked with $-\mathrm{OH}$ groups in starch. ${ }^{15,21}$ The peaks at $-3.2 \mathrm{ppm}$ and $-20 \mathrm{ppm}$ arise from four-coordinated $\mathrm{BX}_{3} \mathrm{~L}$ ( $\mathrm{L}=$ ligand), ${ }^{22}$ which is considered to be from the $\mathrm{B}(-\mathrm{O}-\mathrm{C}-)_{3}$ and $\mathrm{BH}_{3}$ with $\mathrm{THF}$ complex.

FTIR was applied for further confirmation of the reactions among starch and $\mathrm{KH} 560$ and $\mathrm{BH}_{3}$ (see Fig. S3†). New -Si-O-Cand $-\mathrm{B}-\mathrm{O}-\mathrm{C}-$ bonds are observed and the $-\mathrm{OH}$ groups are obviously consumed. These results indicate that the synthesis was carried out as designed.

To identify the thermal stability, thermal gravimetric analysis (TGA) is conducted with StSi and BStSi and the results are shown in Fig. S4. $\dagger$ The decomposition temperature is higher than $150^{\circ} \mathrm{C}$, which is stable enough for the use of ASSLIB below $150{ }^{\circ} \mathrm{C}$.

\section{Electrochemical proprieties}

The dissolving capability of the electrolyte host to lithium salt can be expressed by the ionic conductivity. ${ }^{5 e, 23}$ Fig. 2 a is the ionic conductivity in the range of $-20{ }^{\circ} \mathrm{C}$ to $100{ }^{\circ} \mathrm{C}$. After optimizing the proportion of components and the concentration of lithium salt (shown in Fig. S5 and S6†), the highest ionic conductivity is obtained with a molar ratio of $\mathrm{BH}_{3}$ : starch monomer : KH560 = $1: 5: 4$ and 50 wt\% LiTFSI. It shows an exceptional average ionic conductivity of $3.10 \times 10^{-4} \mathrm{~S} \mathrm{~cm}^{-1}$ at $\mathrm{RT}$. It is also noteworthy that high ionic conductivities of $1.23 \times$
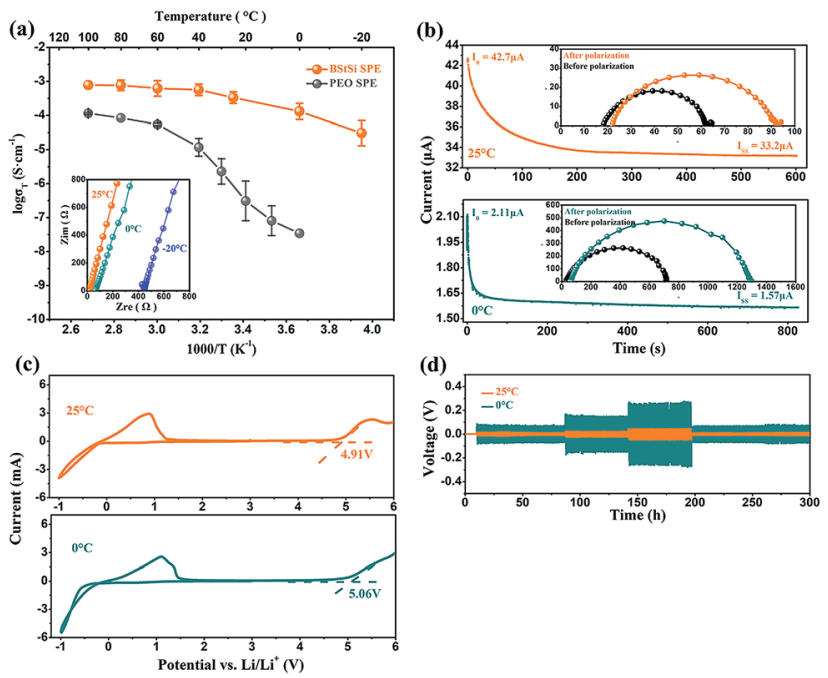

Fig. 2 (a) lonic conductivity of BStSi and PEO SPE. The inset is AC impedance spectra of BStSi. (b) Chronoamperometry of $\mathrm{Li} / \mathrm{BStSi} / \mathrm{Li}$ cells. The inset shows the AC impedance spectra before and after polarization. (c) Cyclic voltammetry of the SS/BStSi/Li cells at a rate of $10 \mathrm{mV} \mathrm{s}^{-1}$. (d) Polarization tests of Li/BStSi/Li cells and the data in Table 1. 
$10^{-4} \mathrm{~S} \mathrm{~cm}^{-1}$ at $0{ }^{\circ} \mathrm{C}$ and $3.10 \times 10^{-5} \mathrm{~S} \mathrm{~cm}^{-1}$ at $-20{ }^{\circ} \mathrm{C}$ are obtained.

The inset in Fig. 2a reveals the AC impedance spectra of the SS/BStSi/SS cells. The values read only $18.2 \Omega$ for $25^{\circ} \mathrm{C}, 63.8 \Omega$ for $0{ }^{\circ} \mathrm{C}$ and $447.9 \Omega$ for $-20^{\circ} \mathrm{C}$, indicating that ions can transfer smoothly in the electrolyte below RT. As a comparison, the temperature dependence of the ionic conductivity was also tested at $30.2 \mathrm{wt} \%$ LiTFSI and $69.8 \mathrm{wt} \%$ PEO of the solid electrolyte. There is an inflection point on the curve around $60{ }^{\circ} \mathrm{C}$, corresponding to the crystalline phase transition temperature $\left(T_{\mathrm{c}}\right)$. Below the $T_{\mathrm{c}}$, the ionic conductivity drops with a decrease of temperature to $4.32 \times 10^{-7} \mathrm{~S} \mathrm{~cm}^{-1}$ at $20{ }^{\circ} \mathrm{C}$ and $3.42 \times$ $10^{-8} \mathrm{~S} \mathrm{~cm}^{-1}$ at $0{ }^{\circ} \mathrm{C}$, only one thousandth of the BStSi solid electrolyte's at $0{ }^{\circ} \mathrm{C}$. From this contrast, it can be deduced that BStSi is exceedingly superior compared to the PEO-based SPE in transferring ions, especially when the temperature goes below RT.

The DC polarization curves of the Li/BStSi/Li cells at $25^{\circ} \mathrm{C}$, $0{ }^{\circ} \mathrm{C}$ and $-20{ }^{\circ} \mathrm{C}$ are shown in Fig. $2 \mathrm{~b}$ and $\mathrm{S} 7 . \dagger$ The values of current and impedance are also listed in Table S1. $\dagger$ According to the Bruce-Vincent-Evans equation, the values of $t^{+}$are calculated to be $0.72,0.79$ and 0.82 at $-20{ }^{\circ} \mathrm{C}, 0{ }^{\circ} \mathrm{C}$ and $25{ }^{\circ} \mathrm{C}$ separately. This high $t^{+}$can be ascribed to the starch structure and cross-linking reactions. Each monomer in starch is equipped with two ether oxygen bonds of -C-O-C-, which present Lewis base property due to two pairs of lone electrons on the oxygen atom. These lone electrons have a weak attraction for lithium ions, making it dissociated from lithium salt effectively. The cross-linking reaction also strengthens the ability of dissociation. The $-\mathrm{B}-\mathrm{O}-\mathrm{C}-$ and $-\mathrm{Si}-\mathrm{O}-\mathrm{C}-$ bonds hold equal effects to the $-\mathrm{C}-\mathrm{O}-\mathrm{C}-$ bonds. This is to say, each monomer in the BStSi host theoretically has five ordered lithium-ion binding sites to provide for the efficient dissociation of lithium salt. Meanwhile, PEO has only one - $\mathrm{C}-\mathrm{O}-\mathrm{C}-$ bond in each monomer so it may require cooperation of 5-6 monomers to dissociate a lithium ion, leading to gridlocks of lithium salt dissociation. ${ }^{12,24}$ On account of this, the BStSi solid electrolyte has a higher $t^{+}$than PEO.

The BStSi solid electrolyte was packed into a SS/BStSi/Li cell to obtain the decomposition potential by linear sweep voltammetry (LSV), as depicted in Fig. $2 \mathrm{c}$ and $\mathrm{S} 8 . \dagger$ The planting potential at $25{ }^{\circ} \mathrm{C}, 0{ }^{\circ} \mathrm{C}$ and $-20{ }^{\circ} \mathrm{C}$ is $-0.15 \mathrm{~V},-0.35 \mathrm{~V}$ and $-0.62 \mathrm{~V}$ respectively, corresponding to the Li deposition on SS. No other peaks are found, which implies the electrochemical stability at the anode/electrolyte interface during reduction process. The $\mathrm{Li}^{+}$stripping peak appears at $0.86 \mathrm{~V}\left(25^{\circ} \mathrm{C}\right), 1.10 \mathrm{~V}$ $\left(0{ }^{\circ} \mathrm{C}\right)$ and $0.90 \mathrm{~V}\left(-20^{\circ} \mathrm{C}\right)$. This indicates that the redox reactions are reversible. In addition, the BStSi solid electrolyte is stable up to $4.91 \mathrm{~V}$ at $25^{\circ} \mathrm{C}, 5.06 \mathrm{~V}$ at $0{ }^{\circ} \mathrm{C}$ and $5.50 \mathrm{~V}$ at $-20^{\circ} \mathrm{C}$, which are higher than that of commercial liquid electrolyte $(\sim 4.5 \mathrm{~V})$. With the wide electrochemical window, the BStSi solid electrolyte will satisfy a cathode with a high potential as well as high capacity.

Besides, a constant current polarization test was conducted with a $\mathrm{Li} / \mathrm{BStSi} / \mathrm{Li}$ symmetric cell to simulate the lithium ion transfer and planting/stripping process, aimed at evaluating the interfacial stability of the electrolyte to lithium anode during cycling. Fig. 2d shows a variation of voltage with time at different current stages. Table 1 lists the average values of polarization potentials and impedances at each current stage, which are $13.7 \mathrm{mV}, 22.0 \mathrm{mV}, 43.7 \mathrm{mV}$ at $25{ }^{\circ} \mathrm{C}$ and $58 \mathrm{mV}$, $128 \mathrm{mV}, 218 \mathrm{mV}$ at $0{ }^{\circ} \mathrm{C}$ for $0.02 \mathrm{~mA}, 0.05 \mathrm{~mA}$ and $0.1 \mathrm{~mA}$ separately. When the current returns to $0.02 \mathrm{~mA}$ after 300 hours cycling, the potentials maintain $11.2 \mathrm{mV}$ at $25^{\circ} \mathrm{C}$ and $60 \mathrm{mV}$ at $0{ }^{\circ} \mathrm{C}$, which displays little disparity with the first $0.02 \mathrm{~mA}$ current stage. This stable polarization impedance indicates that a compatible interface between electrolyte and lithium anode is formed.

\section{Low temperature performance of LFP/BStSi/Li and NCM811/ BStSi/Li batteries}

Fig. 3a demonstrates the superior performance of ASSLIB in capacity and retention at RT as well as in low temperature. At $25^{\circ} \mathrm{C}$ and $0.1 \mathrm{C}$, the initial discharge capacity is $155.7 \mathrm{~mA} \mathrm{~h} \mathrm{~g}^{-1}$ and reaches the maximum discharge capacity of $163.5 \mathrm{~mA} \mathrm{~h} \mathrm{~g}^{-1}$ at the 6th cycle, which is close to the theoretical discharge capacity of LFP (172 $\left.\mathrm{mA} \mathrm{h} \mathrm{g}^{-1}\right)$. The discharge capacity maintains $150.4 \mathrm{~mA} \mathrm{~h} \mathrm{~g}^{-1}$ after 85 cycles. When the C-rate increases to $1 \mathrm{C}$, the batteries presents an average discharge capacity of $120.2 \pm 3.4 \mathrm{~mA} \mathrm{~h} \mathrm{~g}^{-1}$ during 250 cycles (see Fig. S9†).

Furthermore, the battery exhibits appreciable capacity and outstanding cycle life at a lower temperature. The initial discharge capacity is $85 \mathrm{~mA} \mathrm{~h} \mathrm{~g}{ }^{-1}$ at $0{ }^{\circ} \mathrm{C}$ and $0.1 \mathrm{C}$. It increases gradually in the following cycles and achieves $119.7 \mathrm{~mA} \mathrm{~h} \mathrm{~g}^{-1}$ at the 30th cycle. An average discharge capacity of $113.8 \pm$ $5.2 \mathrm{~mA} \mathrm{~h} \mathrm{~g}^{-1}$ is obtained during 200 cycles, which last for about 2500 hours. The long cycle life of the battery can be ascribed to the high lithium-ion transfer ability of the electrolyte and compatible interfaces between electrodes and electrolyte. In addition, the cycling test was also conducted in an extremely cold condition of $-20{ }^{\circ} \mathrm{C}$. An initial discharge capacity of $47.5 \mathrm{~mA} \mathrm{~h} \mathrm{~g}^{-1}$ and an average capacity of $55.9 \pm 3.1 \mathrm{~mA} \mathrm{~h} \mathrm{~g}^{-1}$ (about $31 \%$ of the LFP theoretical specific capacity) are obtained at $0.1 \mathrm{C}$. The charging and discharging curves of 1st, 10th and 50th cycle at $25{ }^{\circ} \mathrm{C}, 0{ }^{\circ} \mathrm{C}$ and $-20^{\circ} \mathrm{C}$ are found in Fig. $3 \mathrm{~b}$. The polarization voltages decrease during cycling, especially, it obviously decreases from $0.69 \mathrm{~V}$ (in 1st cycle) to $0.42 \mathrm{~V}$ (in 50 th cycle) at $-20{ }^{\circ} \mathrm{C}$ that increases the discharge capacity.

It is worth noting that the initial discharge capacity of the $\mathrm{LFP} / \mathrm{BStSi} / \mathrm{Li}$ battery is relatively lower, but there is a capacity increase in the next 5-30 cycles. To better understand this increase, two AC impedance spectra were measured. The spectra of $25{ }^{\circ} \mathrm{C}, 0{ }^{\circ} \mathrm{C}$ and $-20^{\circ} \mathrm{C}$ are shown in Fig. $3 \mathrm{c}$, and the data are listed in Table S2. $\dagger$ Both the bulk resistance $\left(R_{\mathrm{b}}\right)$ and the charge transfer resistance $\left(R_{\mathrm{ct}}\right)$ decrease after cycling. Especially at $-20^{\circ} \mathrm{C}$, it decreases from $9638 \Omega$ (before) to $6241 \Omega$ (after). This decrease may be attributed to the amelioration of compatibility between electrodes and SPE in the first few cycles, which diminishes the charge transfer resistance at the interface.

For further analysis, the diffusion coefficient of lithium ions in LFP was obtained (see Fig. S10 and Table S2 $\dagger$ ). ${ }^{17,25}$ It can be seen that the diffusion coefficient of lithium ions decreases as 
Table 1 The polarization potentials and impedance at different current

\begin{tabular}{c|cccc}
\hline \multirow{2}{*}{$\begin{array}{c}\text { Current/ } \\
\mathrm{mA}\end{array}$} & Potentials $/ \mathrm{mV}$ & Impedance $/ \Omega$ & Potentials $/ \mathrm{mV}$ & Impedance $/ \Omega$ \\
\cline { 2 - 5 } 0.02 & $\mathbf{5 8} \pm 8$ & $2946 \pm 423$ & $13.7 \pm 2.7$ & $\mathbf{5 7 0} \pm 130$ \\
0.05 & $128 \pm 15$ & $2565 \pm 306$ & $22.0 \pm 1.4$ & $463 \pm 28$ \\
0.1 & $218 \pm 24$ & $2184 \pm 245$ & $43.7 \pm 2.0$ & $437 \pm 20$ \\
0.02 & $60 \pm 7$ & $3008 \pm 397$ & $11.2 \pm 1.4$ & $539 \pm 71$ \\
\hline
\end{tabular}

the temperature declines. The coefficient measured at $-20{ }^{\circ} \mathrm{C}$ after cycling is even twice as high as that before cycling. Therefore, it can be concluded that the capacity increase can be attributed to both the ameliorative compatibility and the faster conduction of lithium ions at the interface of the electrodes and electrolyte.

Fig. $3 \mathrm{~d}$ is the rate performance of the LFP/BStSi/Li battery at $0{ }^{\circ} \mathrm{C}$. The average discharge capacities are $109.5 \pm 2.1 \mathrm{~mA} \mathrm{~h} \mathrm{~g}^{-1}$, $91.3 \pm 2.2 \mathrm{~mA} \mathrm{~h} \mathrm{~g}^{-1}, 74.0 \pm 1.7 \mathrm{~mA} \mathrm{~h} \mathrm{~g}^{-1}, 55.0 \pm 1.1 \mathrm{~mA} \mathrm{~h} \mathrm{~g}^{-1}$, $75.1 \pm 1.7 \mathrm{~mA} \mathrm{~h} \mathrm{~g}^{-1}, 99.6 \pm 1.7 \mathrm{~mA} \mathrm{~h} \mathrm{~g}^{-1}, 109.7 \pm 1.0 \mathrm{~mA} \mathrm{~h} \mathrm{~g}^{-1}$ for $0.1 \mathrm{C}, 0.3 \mathrm{C}, 0.5 \mathrm{C}, 1 \mathrm{C}, 0.5 \mathrm{C}, 0.3 \mathrm{C}$ and $0.1 \mathrm{C}$. The discharge capacities are completely restored, showing an excellent rate recovery performance of the battery.
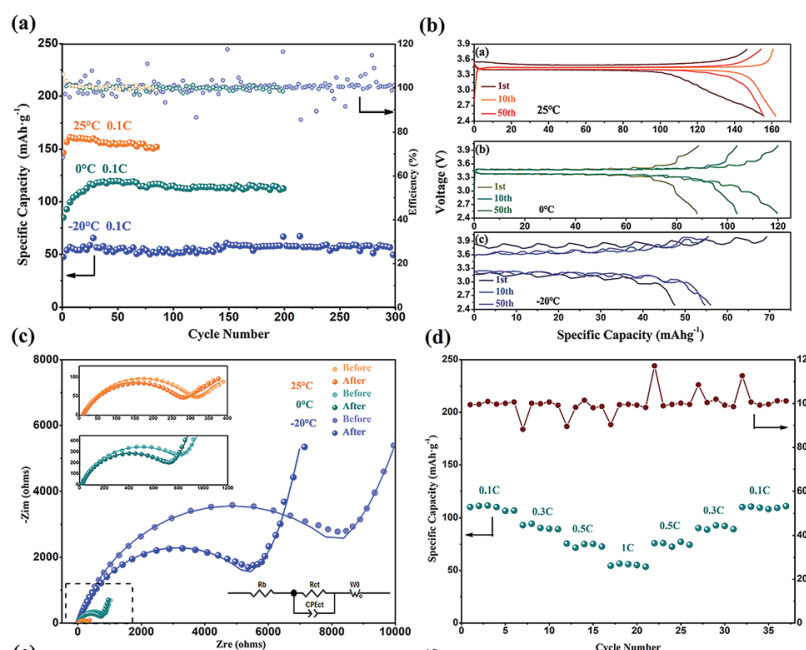

(e)


Fig. 3 (a) Cycle performance of the LFP/BStSi/Li batteries. (b) The charge and discharge curves of the LFP/BStSi/Li batteries. (c) Comparative AC impedance spectra of the LFP/BStSi/Li batteries before cycling and after 10 th cycle. The inset: zoom in the $25^{\circ} \mathrm{C}$ and $0{ }^{\circ} \mathrm{C}$ spectra and the equivalent circuit. (d) Rate performance of the LFP/BStSi/Li batteries at $0{ }^{\circ} \mathrm{C}$. (e) Cycle performances of the NCM811/ $\mathrm{BStSi} / \mathrm{Li}$ batteries at an increasing charge cut-off voltage of $4-4.3 \mathrm{~V}$ and (f) at a constant charge cut-off voltage of $4.2 \mathrm{~V}$.
With the advantage of higher voltage, the $\mathrm{LiNi}_{0.8} \mathrm{Co}_{0.1} \mathrm{Mn}_{0.1} \mathrm{O}_{2}$ (NCM811)/BStSi/Li batteries were assembled, and the discharge performance was investigated at $0{ }^{\circ} \mathrm{C}, 25{ }^{\circ} \mathrm{C}$ and $45{ }^{\circ} \mathrm{C}$ with an increasing charge cut-off voltage from 4.0-4.3 V. As shown in Fig. 3e, the discharge capacity increases when the voltage increases and reaches $165 \pm 3.0 \mathrm{~mA} \mathrm{~h} \mathrm{~g}^{-1}\left(45^{\circ} \mathrm{C}, 0.2 \mathrm{C}\right), 134 \pm 2.3 \mathrm{~mA} \mathrm{~h} \mathrm{~g}^{-1}$ $\left(25^{\circ} \mathrm{C}, 0.2 \mathrm{C}\right)$ and $126 \pm 6.5 \mathrm{~mA} \mathrm{~h}{ }^{-1}\left(0^{\circ} \mathrm{C}, 0.1 \mathrm{C}\right)$ at $4.2 \mathrm{~V}$. But it has overcharging when the voltage rises to $4.3 \mathrm{~V}$. Also, the cycle performance of NCM811/BStSi/Li batteries with a constant voltage range from $2.8-4.2 \mathrm{~V}$ at $25{ }^{\circ} \mathrm{C}$ and $0{ }^{\circ} \mathrm{C}$ are shown in Fig. 3f. The initial discharge capacity at $25^{\circ} \mathrm{C}$ is $157.3 \mathrm{~mA} \mathrm{~h} \mathrm{~g}{ }^{-1}$ and obtains $123.3 \mathrm{~mA} \mathrm{~h} \mathrm{~g}^{-1}$ at the 30 cycle. The initial discharge capacity at $0{ }^{\circ} \mathrm{C}$ is $121.3 \mathrm{~mA} \mathrm{~h} \mathrm{~g}^{-1}$ but it attenuates in the following cycles. As a contrast, the PEO solid electrolyte was used to assemble the NCM811/PEO SPE/Li battery at $60{ }^{\circ} \mathrm{C}$ and $0.1 \mathrm{C}$ in Fig. S11 $\dagger$ (the PEO-LiTFSI electrolyte can work only above $60{ }^{\circ} \mathrm{C}$ ). After 4 cycles, the coulombic efficiency drops and the capacity fades. This comparison reveals the BStSi solid electrolyte is more applicable to NCM811 than the PEO-based solid electrolyte.

\section{Conclusions}

In summary, we have prepared a starch-based solid electrolyte that can satisfy the requirements of ASSLIB operating in low temperature and higher voltage. Our principle is to create sufficient and orderly -O-C-O-like structure to effectively dissociate the lithium salt and improve the lithium ion transfer capability. We choose starch as a basic material because its monomer is originally equipped with two -O-C-O- bonds as well as three $-\mathrm{OH}$ groups that possess an equivalent function for lithium salt dissociation after modification. Through two crosslinking reactions of $\mathrm{KH} 560$ and $\mathrm{BH}_{3}$ with starch, the ionic conductivity and the film-forming properties of the solid electrolyte are obviously enhanced. The ASSLIBs demonstrate extraordinary discharge capabilities at RT and $0{ }^{\circ} \mathrm{C}$, even at $-20{ }^{\circ} \mathrm{C}$. This work provides a method to solve the current challenges of ASSLIB's and widens their applicable scope.

\section{Conflicts of interest}

There are no conflicts to declare.

\section{Acknowledgements}

This work was supported by the Chinese Academy of Engineering (2016-XY-18), the National Natural Science Foundation of China (Grant no. 51274239) and the Foundation of Central South University (CSU) Graduate Student Studying Abroad.

\section{Notes and references}

1 (a) K. Takada, Acta Mater., 2013, 61(3), 759-770; (b) J. Li, C. Ma, M. Chi, C. Liang and N. J. Dudney, Adv. Energy Mater., 2015, 5(4), 1401408; (c) P. G. Balakrishnan, R. Ramesh and T. Prem Kumar, J. Power Sources, 2006, 155(2), 401-414; (d) S. Xin, Y. You, S. Wang, H.-C. Gao, Y.-X. Yin and Y.-G. Guo, ACS Energy Lett., 2017, 2(6), 1385- 
1394; (e) Y. J. Li, C. Y. Fan, J. P. Zhang and X. L. Wu, Dalton Trans., 2018, 47(42), 14932-14937; (f) Y. Y. Wang, W. Y. Diao, C. Y. Fan, X. L. Wu and J. P. Zhang, Chem.-Eur. J., 2019, 25(38), 8975-8981.

2 (a) X. Chen, W. He, L.-X. Ding, S. Wang and H. Wang, Energy Environ. Sci., 2019, 12(3), 938-944; (b) W. Zhou, Z. Wang, Y. Pu, Y. Li, S. Xin, X. Li, J. Chen and J. B. Goodenough, Adv. Mater., 2019, 31(4), e1805574; (c) T. Dong, J. Zhang, G. Xu, J. Chai, H. Du, L. Wang, H. Wen, X. Zang, A. Du, Q. Jia, X. Zhou and G. Cui, Energy Environ. Sci., 2018, 11(5), 1197-1203; (d) J. Lopez, Y. Sun, D. G. Mackanic, M. Lee, A. M. Foudeh, M. S. Song, Y. Cui and Z. Bao, Adv. Mater., 2018, 30(43), e1804142.

3 D. E. Fenton, J. M. Parker and P. V. Wright, Polymer, 1973, 14(11), 589.

4 (a) Y. Gao, B. Hu, Y. Yao and Q. Chen, Chemistry, 2011, 17(32), 8941-8946; (b) P. V. Wright, Electrochim. Acta, 1998, 43(10-11), 1137-1143; (c) S. Seki, M. A. B. H. Susan, T. Kaneko, H. Tokuda, A. Noda and M. Watanabe, J. Phys. Chem. B, 2005, 109(9), 3886-3892.

5 (a) L. Edman, M. M. Doeff, A. Ferry, J. Kerr and L. C. De Jonghe, J. Phys. Chem. B, 2000, 104(15), 3476-3480; (b) I. Rey, J. L. Bruneel, J. Grondin, L. Servant and J. C. Lassègues, J. Electrochem. Soc., 1998, 145(9), 30343042; (c) D. T. Hallinan and N. P. Balsara, Annu. Rev. Mater. Res., 2013, 43(1), 503-525; (d) F. Croce, G. B. Appetecchi and L. Persi, Nature, 1998, 394(6692), 456; (e) O. Buriez, Y. B. Han, J. Hou, et al., J. Power Sources, 2000, 89(2), 149155.

6 (a) Y.-H. Li, X.-L. Wu, J.-H. Kim, S. Xin, J. Su, Y. Yan, J.-S. Lee and Y.-G. Guo, J. Power Sources, 2013, 244, 234-239; (b) X.-L. Wu, Y.-H. Li, N. Wu, S. Xin, J.-H. Kim, Y. Yan, J.-S. Lee and Y.-G. Guo, Solid State Ionics, 2013, 245-246, 1-7. 7 (a) C. Yuan, J. Li, P. Han, Y. Lai, Z. Zhang and J. Liu, J. Power Sources, 2013, 240, 653-658; (b) K. Zhu, Y. Liu and J. Liu, RSC Adv. , 2014, 4(80), 42278-42284; (c) Y. Lin, X. Wang, J. Liu and J. D. Miller, Nano Energy, 2017, 31, 478-485.
8 (a) A. Imberty, A. Buléon, V. Tran and S. Péerez, Starch-Stärke, 1991, 43(10), 375-384; (b) Y. Takeda, T. Shitaozono and S. Hizukuri, Starch-Stärke, 1988, 40(2), 51-54.

9 G. Lammers, E. J. Stamhuis and A. A. Beenackers, Ind. Eng. Chem. Res., 1993, 32(5), 835-842.

10 K. Liao, S. Wu, X. Mu, et al., Adv. Mater., 2018, 30(36), 1705711.

11 (a) P. Han, Y. Zhu and J. Liu, J. Power Sources, 2015, 284, 459465; (b) Y. Lin, J. Li, K. Liu, Y. Liu, J. Liu and X. Wang, Green Chem., 2016, 18(13), 3796-3803.

12 O. Borodin and G. D. Smith, Macromolecules, 2006, 39(4), 1620-1629.

13 H. Tobita and A. E. Hamielec, Polymer, 1990, 31(8), 15461552.

14 H. S. Lee, X. Q. Yang, C. L. Xiang, et al., J. Electrochem. Soc., 1998, 145(8), 2813-2818.

15 J. Xu, J. Li, Y. Zhu, K. Zhu, Y. Liu and J. Liu, RSC Adv., 2016, 6(24), 20343-20348.

16 J. Evans, C. A. Vincent and P. G. Bruce, Polymer, 1987, 28(13), 2324-2328.

17 H. Liu, C. Li, H. P. Zhang, L. J. Fu, Y. P. Wu and H. Q. Wu, J. Power Sources, 2006, 159(1), 717-720.

18 X. Wang, H. Hao, J. Liu, T. Huang and A. Yu, Electrochim. Acta, 2011, 56(11), 4065-4069.

19 (a) E. Lippmaa, M. Maegi, A. Samoson, G. Engelhardt and A. R. Grimmer, J. Am. Chem. Soc., 1980, 102(15), 48894893; (b) V. F. F. Barbosa, K. J. D. MacKenzie and C. Thaumaturgo, Int. J. Inorg. Mater., 2000, 2(4), 309-317.

20 R. Dupree, D. Holland, P. W. McMillan and R. F. Pettifer, J. Non-Cryst. Solids, 1984, 68(2-3), 399-410.

21 P. J. Bray, Inorg. Chim. Acta, 1999, 289(1-2), 158-173.

22 S. Hermanek, Chem. Rev., 1992, 11(2), 325-362.

23 A. Munar, A. Andrio, R. Iserte and V. Compañ, J. Non-Cryst. Solids, 2011, 357(16-17), 3064-3069.

24 Z. Stoeva, I. Martin-Litas, E. Staunton, Y. G. Andreev and P. G. Bruce, J. Am. Chem. Soc., 2003, 125(15), 4619-4626.

25 A. J. Bard, L. R. Faulkner, J. Leddy and C. G. Zoski, Electrochemical methods: fundamentals and applications, Wiley, New York, 1980, vol. 2. 